\title{
Dorsal pancreatic agenesis: description of CT signs
}

\author{
Sonia Sandip, S H Chandrashekhara, Rohit Kumar Khandelwal, Usha Thingujam
}

Department of Radiodiagnosis, All India Institute of Medical Sciences, New Delhi, India

Correspondence to Dr Rohit Kumar Khandelwal, drrohitkhandelwal@gmail.com

Accepted 16 September 2015

\section{CrossMark}

To cite: Sandip S, Chandrashekhara SH,

Khandelwal RK, et al. BMJ Case Rep Published online: [please include Day Month Year] doi:10.1136/bcr-2015210093

\section{DESCRIPTION}

Agenesis of the dorsal pancreas is rare and is characterised by the absence of the body and tail of the pancreas. ${ }^{1}$ Patients with agenesis of the dorsal pancreas often present with non-specific abdominal symptoms and very often it is an incidental finding. However, in approximately $50 \%$ patients, associated hyperglycaemia is noted. ${ }^{2}$

Two useful signs (dependent stomach sign and dependent intestine sign) are described in multidetector CT (MDCT) for differentiation of the distal pancreatic agenesis from other differentials such as pancreatic lipomatosis and atrophy of the pancreas. ${ }^{3}$ In cases of distal pancreatic lipomatosis, abundant fat tissue is seen anterior to the splenic vein. Similarly, pancreatic atrophy shows fatty replacement anterior to the splenic vein. In contrast, in cases of distal pancreatic agenesis, the distal pancreatic bed is occupied by the stomach or intestine, which abuts the splenic vein. ${ }^{3}$

We present the CT imaging of a 60 -year-old man in whom dorsal pancreatic agenesis was incidentally detected. The CT scan (figure 1) revealed the absence of the body and tail of the pancreas with 'dependent stomach sign' and 'dependent intestine sign', which were seen as stomach and small bowel loops lying in the distal pancreatic bed directly anterior to the splenic vein.

\section{Learning points}

The dependent stomach sign and dependent intestine sign are hallmarks of dorsal pancreatic agenesis, differentiating it from pancreatic atrophy and pancreatic lipomatosis.

Competing interests None declared.

Patient consent Obtained.

Provenance and peer review Not commissioned; externally peer reviewed.

\section{REFERENCES}

1 Zhou Y, Chen M, Liu Y. Agenesis of dorsal pancreas confirmed by three-dimensional reconstruction CT. Int J Clin Exp Med 2014:7:3110-12

2 Schnedl WJ, Piswanger-Soelkner C, Wallner SJ, et al. Agenesis of the dorsal pancreas. World J Gastroenterol 2009;15:376-7.

3 Karcaaltincaba M. CT differentiation of distal pancreas fat replacement and distal pancreas agenesis. Surg Radiol Anat 2006;28:637-41. 
Copyright 2015 BMJ Publishing Group. All rights reserved. For permission to reuse any of this content visit http://group.bmj.com/group/rights-licensing/permissions.

BMJ Case Report Fellows may re-use this article for personal use and teaching without any further permission.

Become a Fellow of BMJ Case Reports today and you can:

- Submit as many cases as you like

- Enjoy fast sympathetic peer review and rapid publication of accepted articles

- Access all the published articles

- Re-use any of the published material for personal use and teaching without further permission

For information on Institutional Fellowships contact consortiasales@bmjgroup.com

Visit casereports.bmj.com for more articles like this and to become a Fellow 